\title{
Donabedian's Legacy: The Future of HEALTH CARE QuALITY LAW AND POLICY
}

\author{
KRISTIN MADISON*
}

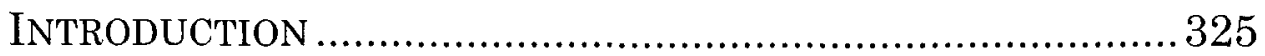

I. HEALTH CARE QUALITY REGULATION IN_HISTORICAL

Perspective

II. The Last Quarter Century of Health Care Quality

LAW AND POLICY .....

III. The NEXT QUARTER CENTURY OF HEALTH CARE QUALITY

LAW AND POLICY: HoPES AND PREDICTIONS

A. Predictions about Quality Law and Policy ................ 345

B. Hopes for Quality Law and Policy................................353

1. Improvement in Quality Measurement

Capabilities

2. Consolidation-related Improvements in Quality... 357

3. Stronger External Oversight Mechanisms 359

4. Systematic Use of Quality Metrics in All Health-

Related Policies and Programs 362

IV. CONCLUSION 363

\section{INTRODUCTION}

The organizers of this symposium assigned me a challenging task: to imagine the next twenty-five years of quality-related health care law. If the same question were put to me twenty-five years ago, my answer would have been wildly off the mark, and not just because I was still in high school. The world of health care quality law, policy, and practice changed tremendously between 1987 and 2012. It also looked quite different in 1987 than it did 1962. To envision health care quality law and policy in 2037 would require a truly robust imagination. Suspecting that my own imagination would not be up to the task, I decided to answer a somewhat different version of the organizers' question: given the path that health care law and policy has taken in reaching its current form, what is its likely future

\footnotetext{
* Professor of Law and Health Sciences, Northeastern University.
} 
trajectory? And then, to add back in a bit of the imagination required by the original exercise, I added a second question: what do you hope will change over the next twenty-five years? This essay offers answers to both these questions.

Part I of the essay begins the analysis by examining the state of health care quality law as it existed throughout much of the twentieth century. In 1900, two legal tools featured prominently in the health care quality toolbox: malpractice law and professional licensure. By their nature, both are limited in what they can accomplish, but this fact seemed to be of little concern to legal commentators. The absence of sustained discussion of health care quality deficiencies in law journals of this era is striking. It was not until the 1970s and early 1980s that a few legal scholars, motivated in part by federal reform efforts directed at controlling costs, began to take a more comprehensive look at mechanisms for quality oversight.

By the 1980s, health care quality law, policy, and practice had begun to experience a major shift in focus. As Professor Timothy Jost explained in a 1995 article, "over time the focus of regulation [ changed from assurance of minimal professional competence . . . to consideration of quality as more globally defined." 1 Part II attributes this shift to several factors, including a growing commitment to building an evidence base for medical practice, a firmer analytic foundation for assessing health care quality, and a rapidly accumulating body of research documenting deficiencies in care. Legal scholars of the late 1980s and early 1990s wrote a number of articles exploring the shift's implications for law and policy; Part II reviews some of their insights.

The trend toward health care quality measurement that began to accelerate twenty-five years ago continues today. Many recently established quality improvement policies and programs, including those embodied in the Patient Protection and Affordable Care Act, reflect this trend. Part III describes these programs and highlights policymakers'

1 Timothy Stoltzfus Jost, Oversight of the Quality of Medical Care: Regulation, Management, or the Market, 37 ARIZ. L. REV. 825, 826 (1995). 
efforts to respond to concerns previously raised by legal scholars. Part III predicts that the trend will continue for the foreseeable future, and then comments in more detail about the paths that quality measure-based reforms might take.

While this essay expresses a mostly sanguine view of the evolution of health care quality law and policy, there remain many areas of concern and uncertainty and much room for improvement. The second part of Part III illuminates these issues by describing directions in which I hope that quality measure-based law and policy will go. It discusses ways that the evidence base for measurement and reporting could be improved, explores the implications of increasing consolidation among health care providers, and considers how quality measures could be integrated into more traditional quality oversight mechanisms. Finally, it expresses the hope that the increasing availability of quality measures will foster a greater willingness to engage in health system experimentation.

Part IV concludes with observations about the future of quality improvement efforts in a world increasingly concerned about health care costs.

\section{HEALTH CARE QUALITY REGULATION IN HISTORICAL PERSPECTIVE}

A leading health law scholar once identified health care quality as the primary concern of health law during the first half of the twentieth century. ${ }^{2}$ This conclusion is not surprising, given the long history of two legal mechanisms intended to address quality deficits: medical malpractice law and medical licensure. The principles of tort law allowed injured patients to seek remedies for quality deficits well before $1900,{ }^{3}$ while modern physician licensing regimes

2 See Arnold J. Rosoff, Health Law at Fifty Years: A Look Back, 14 HEALTH MATRIX 197, 198 (identifying health care quality as the primary concern of health law during the first half of the twentieth century).

3 See George J. Annas, Doctors, Patients, and Lawyers - Two Centuries of Health Law, 367 NEw ENG. J. MED. 445, 445-49 (2012) (discussing the history of malpractice litigation); Andrew A. Sandor, The 
had their origins in the late 1800 s, when many states across the country enacted, or re-enacted, physician licensure laws. 4

Scholarly articles published in the early and midtwentieth century simultaneously highlight both the importance of tort law and licensure as mechanisms for policing quality, and the limitations of these mechanisms. A student comment in the Yale Law Journal from the 1930s, for example, examines hospital liability for torts of hospital medical staffs, arguing that "[r]ules of liability should be framed to assure competent medical care, and yet the development of hospital facilities must not be discouraged."5 Numerous articles discuss the problems of licensure regimes; an article from 1909 discusses constitutional issues surrounding medical licensure law, ${ }^{6}$ while articles from the 1940s such as Legal Control of Medical Charlatanism ${ }^{7}$ and Legal Control of Medical Practice: Validity and Methods ${ }^{8}$ discuss the difficulties of using the licensure regime to police the qualifications of physicians.

While scholars of this era discuss ways to make these legal tools work better, they do not seem to focus on the inherent limits of these tools. Malpractice law discourages physicians from departing from the norms established by their colleagues, while licensure's requirements exclude from practice those whose training is deemed insufficient to

History of Professional Liability in the United States, 163 JAMA 459, 460 (1957) (citing a 1794 case as the first reported American malpractice case). For an example of a malpractice case from the $1800 \mathrm{~s}$, see Small v. Howard, 127 Mass. 131, 135 (1880).

4 PaUl Starr, THE SOCIAL TRANSFORMation OF AMERICAN MEDICINE 104 (1982).

5 Liability of Hospital for Injuries to Patients Using Hospital Facilities, 48 YALE L.J. 81, 81 (1938).

6 H.B. Hutchins, Characteristics and Constitutionality of Medical Legislation, 7 MICH. L. REV. 295 (1909).

7 S. Earl Heilman, Legal Control of Medical Charlatanism, 22 N.C. L. REV. 23 (1943) (discussing licensure regimes and the use of legal tools such as injunctions to preclude unauthorized practice of medicine).

8 Kenneth C. Sears, Legal Control of Medical Practice: Validity and Methods, 44 MiCH. L. REV. 689 (1946) (discussing various licensing issues, including due process considerations, equal protection concerns, and enforcement methods). 
practice competently. Even if these tools function as they should, their potential to encourage quality improvement is quite limited. Adhering to medical custom will do little to improve health outcomes if the custom embodies poor quality care. Licensure can exclude the most poorly trained providers, but it does nothing to encourage higher-quality care among those who have surpassed the requisite threshold.

The broad topic of health care quality, however, did not seem to occupy the attention of health law scholars. Many of the health-related articles published in the early to mid1900 s focused on topics such as public health ${ }^{9}$ and the public financing of health care,$^{10}$ rather than on health care delivery. A search of the HeinOnline Law Journal Library database for law review articles published before the 1980 s $^{11}$ revealed only one with a title containing the term "medical error," and it was about patient error, not provider error. ${ }^{12}$ Written in the $1890 \mathrm{~s}$, the article considered how best to address "the popular overestimate of the potency of drugs." 13 In other words, the article was motivated by the same concern that figured in both licensure regimes and

9 Chester James Antieau, The Power of Municipal Corporations to Protect the Public Health and Safety, 1951 WASH. U. L. REV. 358 (1951); Ray A. Brown, Legislation for Health and Personal Safety - Police Power, 42 HARV. L. REV. 866 (1929); Marc A. Franklin, Medical Mass Screening Programs: A Legal Appraisal, 47 CoRNELL L. REV. 205 (1961); James A. Tobey, Public Health and the Police Power, 4 N.Y.U. L. REV. 126 (1927).

10 See, e.g., Joseph P. Chamberlain, The Practicability of Compulsory Sickness Insurance in America, 4 AM. LAB. LEGIS. REV. 49 (1914); I.S. Falk, An Introduction to National Problems in Medical Care, 6 LAW \& CONTEMP. PROBS. 497 (1939).

11 The author used the HeinOnline Law Journal Library's Advance Search Function to enter the searches "medical error," "iatrogenic," "title: "medical error," and "title: 'quality," available at http://home. heinonline.org/library-corner/resources/widget/. The search included all indexed articles, comments, notes, and reviews with publication dates before 1980 .

12 E.P. Buffet, A Popular Medical Error to Be Corrected by the Physician, 14 MEDICO-LEGAL J. 52 (1896).

$13 \quad I d$. at 53. 
malpractice cases of that era: quackery. ${ }^{14}$ The next mention of "medical error" in a title did not occur until 1981, when Professor Barry Furrow published an article arguing that malpractice litigation might help improve health care quality. 15

Expanding the search of early and mid-twentieth century law review articles to include a broader set of quality-related search terms turned up few additional examples. Health care quality was sometimes briefly mentioned in articles focusing on other health-related subjects, such as health insurance, ${ }^{16}$ but was rarely at the center of articles. By the 1960s and 1970s, some law review articles began to include more sustained discussions of health care quality, but their focus was often quite narrow. One group of articles fitting this description focused on food and drug law. ${ }^{17}$ The Furrow article belonged to a second group: articles discussing medical errors or quality deficiencies in the context of medical malpractice litigation,

14 The 1880 Massachusetts case Small v. Howard considered whether by referring to "others in the profession," a jury instruction might allow the standard of care to include practices of "all the mountebanks, ignorant pretenders, and imposters who undertake the practice of medicine and surgery." Small v. Howard, 127 Mass. 131, 135 (1880).

15 Barry R. Furrow, Iatrogenesis and Medical Error: The Case for Medical Malpractice Litigation, 9 J.L. MED. \& ETHICS 4, 4 (1981).

16 See, e.g., Comment, The Essentials of an Adequate Health Program, 59 YALE L.J. 292, 303 (1950) ("The patient does not have the knowledge to select health care personnel on the basis of the quality of care given."); Anne R. Somers \& Herman M. Somers, Health Insurance: Are Cost and Quality Controls Necessary?, 13 INDUS. \& LAB. REL. REV. 581 (1960) ("In the group practice environment, where the physicians' services are regularly under the scrutiny of professional colleagues and comparisons are virtually impossible to avoid, the positive effect on the quality of care has frequently been noted.").

17 See, e.g., William A. Carpenter, Jr., The Federal Food Drug and Cosmetic Act as an Experiment in Quality Control, 20 SYRACUSE L. REV. 883 (1969); Wilbur A. Gould, Why Quality Control, 19 FoOD DRUG CosM. L.J. 217 (1964). The search also identified several articles focusing on quality in nursing homes. See, e.g., Patricia A. Butler, Assuring the Quality of Care and Life in Nursing Homes: The Dilemma of Enforcement, 57 N.C. L. REV. 1317 (1979). 
a hot topic in the aftermath of the 1970s malpractice crisis. ${ }^{18}$

In 1970, the journal Law and Contemporary Problems published a series of articles from a symposium organized by Professor Clark Havighurst that did take a broader perspective on health care quality. The symposium was motivated not by a general desire to craft new approaches to quality improvement, but instead by a desire to "facilitate the formulation of the national health care program that will best meet the nation's needs." 19 Within this context, "maintaining high quality standards" was a concern given "rapid change and serious shortages of essential resources." 20 Symposium articles provided an overview and critique of the many quality regulation mechanisms in place, a list that had expanded beyond tort liability and professional licensure to include facility licensure, accreditation, certification, and institutional controls, among other mechanisms. ${ }^{21}$

Several bursts of quality-related scholarship in the latter part of the twentieth century followed the pattern established by the 1970 symposium: they focused on quality concerns that were tied to the financing of care. For

18 Robert H. Brook, Rudolf L. Brutoco \& Kathleen N. Williams, The Relationship Between Medical Malpractice and Quality of Care, 6 DUKE L.J. 1197 (1975); Comparative Approaches to Liability for Medical Maloccurrences, 84 YALE L.J. 1141 (1975); Clark C. Havighurst \& Laurence R. Tancredi, Medical Adversity Insurance - A No-Fault Approach to Medical Malpractice and Quality Assurance, 1974 INS. L.J. 69 (1974); Reid F. Holbrook \& Lee J. Dunn Jr., Medical Malpractice Litigation: The Discoverability and Use of Hospitals' Quality Assurance Records, 16 WASHBURN L.J. 54 (1977); M.W. Reder, An Economic Analysis of Medical Malpractice, 5 J. LEGAL STUD. 267 (1976).

19 Clark C. Havighurst, Foreword, 35 LAW \& CONTEMP. PROBS. 229 (1970).

20 Id.

21 Rick J. Carlson, Health Manpower Licensing and Emerging Institutional Responsibility for the Quality of Care, 35 LAW \& CONTEMP. Probs. 849 (1970); Milton I. Roemer, Controlling and Promoting Quality in Medical Care, 35 LAW \& ConTEMP. PROBS. 284 (1970); William Worthington \& Laurens H. Silver, Regulation of Quality of Care in Hospitals: The Need for Change, 35 LAW \& CoNTEMP. PROBS. 305 (1970). For an excellent account of the evolution of quality oversight over the twentieth century, see Jost, supra note 1, at 827-41. 
example, several articles from the mid-1970s examined the role of professional standards review organizations (PSROs) in controlling costs and ensuring the quality of hospital care delivered to Medicare beneficiaries; an article by Professors Clark Havighurst and James Blumstein explicitly considered the balancing of cost and quality concerns within this framework. ${ }^{22}$ In the early 1980 s, Medicare adopted a prospective payment system under which it paid hospitals a fixed amount for each patient admission, providing a financial incentive to hospitals to reduce costs per admission; several law review articles, including one by Professor Wendy Mariner, considered the quality implications of this new approach to financing care. ${ }^{23}$ An article from the mid-1980s considered the tensions between cost containment efforts and the application of quality standards in medical malpractice litigation. ${ }^{24}$ These articles evidenced a growing interest among the legal academic community in mechanisms for ensuring health care quality in a rapidly changing health care world.

\section{The Last QuaRTER CENTURY OF HEALTH CARE QUALITY LAW AND POLICY}

In some ways, the last twenty-five years of health care quality law and policy could be viewed as an extension of the previous one hundred. Medical malpractice liability and professional licensing continued their roles as qualitycontrol mechanisms, although their effectiveness was widely questioned. And health law scholarship continued to devote significant attention to the tensions between quality

22 John R. Ball, PSRO - An Alternative to the Medical Malpractice System as a Quality Assurance Mechanism, 36 MD. L. REV. 566 (1977); Cedric C. Chao, Cost and Quality Control in the Medicare/Medicaid Program: Concurrent Review, 11 HARV. C.R.-C.L. L. REv. 664 (1976); Clark C. Havighurst \& James F. Blumstein, Coping with Quality/Cost Trade-Offs in Medical Care: The Role of PSROs, 70Nw.U.L.REv.6(1976).

23 Wendy K. Mariner, Prospective Payment for Hospital Services: Social Responsibility and the Limits of Legal Standards, 17 CUMB. L. REV. 379 (1987).

24 E. Haavi Morreim, Cost Containment and the Standard of Medical Care, 75 CALIF. L. REV. 1719 (1987). 
and cost controls; while articles from the 1970s discussed PSROs and articles from the 1980s discussed Medicare's prospective payment system, articles from the $1990 \mathrm{~s}$ examined the quality concerns associated with the era's rapidly proliferating managed care organizations. ${ }^{25}$

In other ways, however, both the nature of quality concerns and the legal and policy tools used to address them have evolved considerably in the last twenty-five years. This evolution can be traced to earlier developments in the medical field. A leading quality expert, David Eddy, characterizes the medical world through much of the twentieth century as one in which it was often assumed that "through the rigors of medical education, followed by continuing education, journals, individual experiences, and exposure to colleagues, each physician always thought the right thoughts and did the right things." 26 If training and professional interactions generally result in physicians doing "the right things," then licensure will go far in ensuring quality, and the liability system may provide the right incentives for high-quality care. In such a world, it makes perfect sense to focus on licensure and other peerreview based mechanisms, along with medical liability, to ensure that care is of acceptable quality.

Some individuals, however, recognized that quality concerns might extend beyond those associated with quackery. Ernest Codman, a Boston surgeon, developed a system in the early 1900 s for assessing surgical quality that he hoped would lead to improved care. ${ }^{27}$ But Codman's data collection and analysis system was never put into

${ }_{25}$ William S. Brewbaker III, Medical Malpractice and Managed Care Organizations: The Implied Warranty of Quality, 60 LAW \& CONIEMP. PROBS. 117 (1997); Barry R. Furrow, Managed Care Organizations and Patient Injury: Rethinking Liability, 31 GA L REv. 419 (1997); Clark C. Havighurst, Making Health Plans Accountable for the Quality of Care, 31 GA.LREv. 587 (1997); Diane E. Hoffmann, Emergency Care and Managed Care - A Dangerous Combination, 72 WASH. L REV. 315 (1997); William M. Sage, Enterprise Liability and the Emerging Managed Health Care System, 60 LAW \& CONTEMP.PROBS. 159(1997).

26 David M. Eddy, Evidence-Based Medicine: A Unified Approach, 24 HEALTH AFF. 9, 9 (2005).

27 Michael L. Millenson, DEMANDINGMEDICALEXCELLENCE 143 (1997). 
widespread use, and it was not until much later that researchers began laying the foundation for today's quality improvement efforts. ${ }^{28}$ In the 1950s, for example, Paul Lembcke created a system for conducting "medical audits" as a tool for assessing hospital quality. ${ }^{29}$ The most influential work of this era, however, was Avedis Donabedian's pathbreaking 1966 article, Evaluating the Quality of Medical Care. It explained that quality could be assessed by looking at structures, processes, or outcomes, and then discussed the data and measurement issues that complicated efforts to engage in such assessments. ${ }^{30}$ The work of these and other researchers was critical in developing the tools necessary to conduct systematic quality assessment. ${ }^{31}$

A second, closely related force driving changes in quality-related law and policy was the growth in evidencebased medicine. Rooted in the clinical research that began to accelerate in the $1960 \mathrm{~s}$, evidence-based medicine is a term applied to medical decision-making based on "good evidence of effectiveness and benefit." 32 In the early 1980 s, a

28 Id. at 145. There were, of course, quality improvement initiatives other than Codman's. See generally John M. Luce, Andrew B. Bindman \& Philip R. Lee, A Brief History of Health Care Quality Assessment and Improvement in the United States, 160 W.J. MED. 263, 263-64 (1994) (discussing historical quality improvement efforts); MILLENSON, supra note 27, at 142-47 (1997) (discussing historical quality improvement efforts). Many early reform efforts focused on standard-setting, however, and did not benefit from the systematic study and assessment of quality that became more common late in the century.

29 See George A. Silver, Paul Anthony Lembcke, MD, MPH: A Pioneer in Medical Care Evaluation, 80 AM. J. PUB. HEALTH 342, 345-46 (1990) (discussing Lembcke's contributions to the development of medical care evaluation techniques); MILLENSON, supra note 27, at 15052 (describing Lembcke's work).

30 Avedis Donabedian, Evaluating the Quality of Medical Care, 44 MILBANK MEMORIAL FUND Q. 166, 198-99 (1966).

31 See, e.g., Robert H. Brook \& Francis A. Appel, Quality-of-Care Assessment: Choosing a Method for Peer Review, 288 NEW ENG. J. MED. 1323 (1973) (discussing and applying quality evaluation methodologies).

32 Eddy, supra note 26, at 14 (formally defining evidence-based medicine as a "set of principles and methods intended to ensure that to the greatest extent possible, medical decisions, guidelines, and other types of policies are based on and consistent with good evidence of 
variety of groups began to distill research results into guidelines for medical practice, and subsequently "more and more organizations began to apply evidence-based methods to their work." 33 Once established, guidelines had the potential both to promote the diffusion of evidencesupported high-quality treatment practices, and to facilitate assessment of health care quality based on evidencesupported standards.

As research on health care quality continued into the 1990 s, a related but distinct health care issue captured the attention of legal and medical scholars, medical professionals, and the public: medical error. Medical error had been a topic of both legal and medical research before this period; Professor Furrow's 1981 article on the use of malpractice law to address medical error, for example, drew on several studies that had been published within the previous decade. ${ }^{34}$ And articles on medical error appeared in medical journals even earlier in the century. But many of these articles focused on specific sources of error in diagnosis and testing procedures, rather than engaging in broader examinations of medical error. ${ }^{35}$

effectiveness and benefit"); Gordon Guyatt et al., Evidence-Based Medicine: A New Approach to Teaching the Practice of Medicine, 268 JAMA 2420, 2420 (1992) (noting that a paradigm shift "involv[ing] using the medical literature more effectively in guiding medical practice" had foundations "in developments in clinical research over the last [thirty] years").

33 Eddy, supra note 26, at 12.

34 See Furrow, supra note 15 , at 7 nn. 1-4.

35 A Medline review of pre-1970 titles containing the terms "error" or "iatrogenic" turned up only a few titles that seemed to refer to broader studies of medical error. See W.M. Bartlett, Diagnostic and Therapeutic Errors: A Study of the Causes of Error in 500 Clinical and Necropsy Records, 38 J. MED. ASS'N GA. 331 (1949); Delay in Recognizing Cancer Studied: Iatrogenic or Patient Failure?, 197 JAMA 26 (1966); S.F. Harkness, The Hospital Staff and Iatrogenic Morbidity and Mortality, 57 J. AM. Osteopathic Ass'N 305 (1958); D. Zeman, The Nature of Medical Error; A Study in Applied Medical History, $4 \mathrm{~J}$. Chronic Diseases 648 (1956); George L. Saiger, Observations on the Probability of Error in Medical Diagnosis, 56 ANNALs INTERNAL MED. 860 (1962) (" $[\mathrm{A}] \mathrm{n}$ analysis of how the probability of a diagnostic error can be measured or controlled when population values are known."). 
In the latter part of the twentieth century, by contrast, a broad focus on medical error became more common. The now widely cited Harvard Medical Practice Study made headlines in $1991^{36}$ by establishing the prevalence of adverse events, including negligent adverse events, in New York hospitals. ${ }^{37}$ Professor Lucian Leape published a classic article describing the causes of errors and approaches to error prevention in $1994 .^{38}$ In 1999, the Institute of Medicine published To Err Is Human, ${ }^{39}$ extrapolating from previous studies to suggest that the number of Americans who die from medical errors in a year may be between 44,000 and 98,000, and that more people die annually from medical errors than from car accidents or breast cancer. ${ }^{40}$ These startling statistics made newspaper front pages across the country, ${ }^{41}$ and the report has now been cited many thousands of times. ${ }^{42}$ Academic law journals followed

36 See Hospital Care Hurts $4 \%$ of Patients: Study, CHICAGo SUNTIMES, Feb. 7, 1991, at 28.

37 See Troyen A. Brenan et al., Incidence of Adverse Events and Negligence in Hospitalized Patients: Results of the Harvard Medical Practice Study, 324 NEW ENG. J. MED. 370 (1991) (reporting results on rates of adverse events and negligence among New York hospitals in 1984); Lucian Leape et al., The Nature of Adverse Events in Hospitalized Patients: Results of the Harvard Medical Practice Study II, 324 NEW ENG. J. MED. 377 (1992) (examining adverse events in more detail).

38 Lucian L. Leape, Error in Medicine, 272 JAMA 1851 (1994).

39 Inst. OF MED., To ERR IS HUMAN: BUILDING A SAFER HEALTH System (1999) (Linda T. Kohn, Janet M. Corrigan \& Molla S. Donaldson, eds.).

$40 \quad I d$. at 1.

41 See, e.g., Bob Davis \& Julie Appleby, Medical Mistakes 8th Top Killer, USA TODAY, Nov. 30, 1999, at A1; Lauran Neergaard, ErrorProne Medicine Study: Mistakes Kill Tens of Thousands of People a Year, ORLANDo Sentinel, Nov. 30, 1999, at A1; Robert Pear, Group Asking U.S. for New Vigilance in Patient Safety, N.Y. TIMES, Nov. 30, 1999 , at $\mathrm{A} 1$.

42 Google Scholar suggests that the report has been cited more than 9500 times. See, e.g., Steven H. Woolf, Patient Safety is Not Enough: Targeting Quality Improvements to Optimize the Health of the Population, 140 ANN. INTERNAL MED. 33, 33 (2004). 
the trend by publishing a series of articles on medical error. ${ }^{43}$

The Institute of Medicine's Committee on the Quality of Health Care in America followed up on To Err is Human two years later with a second report that took a broader look at quality in the health care system: Crossing the Qualit. Chasm. ${ }^{44}$ Beginning with the words, "The American health care delivery system is in need of fundamental change," the report reviews evidence of widespread quality deficits and makes recommendations for quality improvement. ${ }^{45}$ The report does not seem to have had as significant an impact as To Err Is Human. One explanation is its lack of the previous report's eye-catching mortality statistics. Another is that by the time the report was published, health care quality and its improvement were already so clearly on the agenda - or at least the radar screen - of health professionals, researchers, and scholars. ${ }^{46}$

Research on quality assessment, the growth of evidencebased medicine, and concerns about changes within the health care system ${ }^{47}$ all contributed to a rapidly-expanding body of empirical research in the latter part of the 20th century. Studies documenting deficiencies in care were

43 See, e.g., Melissa Chiang, Promoting Patient Safety: Creating a Workable Reporting System, 18 YALE J. ON REG. 383 (2001); Joan H. Krause, Medical Errors as False Claims, 27 AM. J.L. \& MED. 181 (2001); Brian A. Liang, The Adverse Event of Unaddressed Medical Error: Identifying and Filling the Holes in the Health Care and Legal Systems, 29 J.L. MED. \& ETHICS 346 (2001). Work on medical errors continues to be published. See, e.g., Michelle M. Mello et al., Who Pays for Medical Errors - An Analysis of Adverse Event Costs, the Medical Liability System, and Incentives for Patient Safety Improvements, $4 \mathrm{~J}$. EMPIRICAL LEGAL STUD. 835 (2007) [hereinafter Mello et al.].

44 Inst. of MED., Crossing THE QUality Chasm: A NEW Health SYSTEM FOR THE 21ST CENTURY (2001) [hereinafter INST. OF MED.].

$45 \quad I d$. at 1.

46 See generally Millenson, supra note 27, at 362 (describing attention to quality issues in the clinical literature in the mid-1990s).

47 A 1973 medical journal article referred to "public pressure and recent Congressional legislation" - legislation related to PSROs - as a reason for increased attention to quality assessment. Brook \& Appel, supra note 31 , at 1323 . 
published in the 1970s and 1980s. ${ }^{48}$ Professor Donabedian's work on health care quality was widely published in the $1980 \mathrm{~s},{ }^{49}$ and by the end of the decade, numerous articles discussing health care quality had appeared in medical journals. ${ }^{50}$ In the 1990 s, there was a steady flow of articles reporting the results of quality studies, while numerous commentators drew attention to the need for further research and the development of strategies to address deficiencies. ${ }^{51}$

It was not just researchers who were interested in analyzing data on quality. By the early 1990s, continuous quality improvement and total quality management techniques had reached the health care industry. Managers in health care organizations had begun to systematically

48 See Eddy, supra note 26, at 10 (discussing John Wennberg's work on geographic variations in health care delivery and RAND studies from the 1980s "showing that large proportions of procedures being performed by physicians were considered inappropriate even by the standards of their own experts").

49 See, e.g., Avedis Donabedian, The Quality of Care: How Can It Be Assessed?, 260 JAMA 1743 (1988); Avedis Donabedian, Quality Assessment and Assurance: Unity of Purpose, Diversity of Means, 25 INQUIRY 173 (1988).

50 See, e.g., R.W. DuBois et al., Hospital Inpatient Mortality: Is It a Predictor of Quality?, 317 NEW ENG. J. MED. 1674 (1987).

51 See, e.g., John Z. Ayanian et al., Quality of Care by Race and Gender for Congestive Heart Failure and Pneumonia, 37 MED. CARE 1260 (1999); David Blumenthal, The Future of Quality Measurement and Management in a Transforming Health Care System, 278 JAMA 1622 (1997); Mark R. Chassin, Assessing Strategies for Quality Improvement, 16 HEALTH AFF. 151 (1997); Mark R. Chassin, Robert W. Galvin \& the National Roundtable on Health Care Quality, The Urgent Need to Improve Health Care Quality, 280 JAMA 1000 (1998); Maria A. Friedman, Issues in Measuring and Improving Health Care Quality, 16 Health CARE FinANCING REviEW 1 (1995); Stephen F. Jencks et al., Quality of Medical Care Delivered to Medicare Beneficiaries: A Profile at State and National Levels, 284 JAMA 1670 (2000); Mark A. Schuster, Elizabeth A. McGlynn \& Robert H. Brook, How Good Is the Quality of Health Care in the United States?, 76 THE MilbanK Q. 517 (1998); Bryan J. Weiner, Jeffrey A. Alexander \& Stephen M. Shortell, Leadership for Quality Improvement in Health Care: Empirical Evidence on Hospital Boards, Managers, and Physicians, 53 MED. CARE RES. \& REV. 397 (1996). For a systematic review of quality articles from this period, see INST. OF MED., supra note 44, at 242-49. 
collect and assess quality-related data within their own institutions. ${ }^{52}$ Improved analytical techniques and data processing abilities, ${ }^{53}$ the ever-present concerns that cost controls would threaten quality, ${ }^{54}$ and a vision of the future that involved quality-based competition ${ }^{55}$ have all been cited as contributors to the sharpening focus on quality issues.

Twenty-five years ago, in 1987, two articles in the health policy journal Health Affairs used the word "quality" in their titles, and one of these articles was really about physician supply. ${ }^{56}$ Between 1987 and 1996, just over two percent of titles included the term "quality." 57 Between 1997

52 See Donald M. Berwick \& Marian G. Knapp, Theory and Practice for Measuring Health Care Quality, HEALth CARE FIn. REV. 49 (1987); Glenn Laffel \& David Blumenthal, The Case for Using Industrial Quality Management Science in Health Care Organizations, 262 JAMA 2869 (1989); Jost, supra note 1, at 838-39 (discussing origins of total quality management and its application to health care); MILLENSON, supra note 27, at 244-67 (chronicling providers' internal quality improvement efforts during the 1980s and 1990s).

53 See Jost, supra note 1, at 836-37 (discussing impact of improved information technologies); Kristin Madison, Regulating Health Care Quality in an Information Age, 40 U.C. DAVIS L. REV. 1577 (2007) (discussing impact of improved information technologies).

54 INST. OF MED., supra note 44, at 231 (pointing to concerns that new organizational structures and reimbursement strategies might sacrifice quality in an effort to control costs as motivating increased attention to quality issues); Timothy Stoltzfus Jost, Regulatory Approaches to Problems in the Quality of Medical Care: Diagnosis and Prescription, 22 U.C. DAvis L. REv. 593, 593-94 (1989) (attributing the "renewed focus on quality assurance" of the late 1980s to "[s]trategies developed in the mid-1980s for coping with medical cost escalation, such as diagnosis-related-group prospective payment, Health Maintenance Organizations (HMOs), and gate-keeper managed care arrangements").

55 Troyen A. Brennan, Improving the Quality of Medical Care: A Critical Evaluation of the Major Proposals, 10 YALE L. \& POL'Y REv. 431, 436 (1992).

56 Robert E. Patricelli, Employers As Managers of Risk, Cost, and Quality, 6 Health AfF. 75 (1987); Ira M. Rutkow, Surgical Operations and Supply: Assessing Future Quality, 6 HEALTH AFF. 82 (1987) (discussing physician supply and surgical operations).

57 As of March 30, 2013, an "Advanced Search" completed on the HEALTH AFFAIRS website shows that when the search is restricted to the years 1987 and 1996, with no further restrictions on article content, 1371 articles are found. Further restricting the search to include only 
and July 2012, that percentage more than doubled to over four and a half percent. ${ }^{58}$ Over the last quarter century, quality has come to occupy an increasingly prominent position on the agenda of providers, researchers, and policymakers.

What did this shift mean for health care law in the last quarter century? The 19th century tools for quality control, licensure and tort liability, are still around, but much policymaker and scholarly effort has been directed at finding ways to improve their usefulness in ensuring health care quality. ${ }^{59}$ For example, policymakers sought to improve peer review and professional discipline mechanisms through the passage of the Health Care Quality Improvement Act of 1986.60 Legal scholars, meanwhile, sought to build a foundation for medical liability reform by carefully analyzing the relationship between the liability system and quality. ${ }^{61}$

But the quality revolution also launched a new line of thinking among legal scholars about ways of ensuring high quality care. One of the authors in the 1970 issue of Law and Contemporary Problems, Rick J. Carlson, foreshadowed later scholarship in the area by referencing Donabedian's

titles including the word "quality" returned 28 articles, which is two percent of 1371 .

58 A search using the "Advanced Search" function on the HEALTH AFFAIRS website found 5222 articles published between 1997 and July 2012 , of which 240 included the word "quality" in their titles.

59 See Kristin M. Madison, From HCQIA to the ACA: The Evolution of Reporting as $A$ Quality Improvement Tool, 33 J. LEGAL MED. 63, 65-67 (2012) (describing historical concerns about licensing and peer review as tools for ensuring quality).

60 See id. at 67-68 (describing Health Care Quality Improvement Act of 1986); Health Care Quality Improvement Act of 1986 (HCQIA), 42 U.S.C. $\S 11101$.

61 See, e.g., Brennan, supra note 55; David A. Hyman \& Charles Silver, The Poor State of Health Care Quality in the U.S.: Is Malpractice Liability Part of the Problem or Part of the Solution, 90 CORNELLL REV. 893 (2005); Michelle M. Mello \& Troyen A. Brennan, Deterrence of Medical Errors: Theory and Evidence for Malpractice Reform, 80 TEX L REV. 1595 (2001); Mello et al, supra note 43; William M. Sage, Kathleen E. Hastings \& Robert A. Berenson, Enterprise Liability for Medical Malpractice and Health Care Quality Improvement, 20 AM J.L \&MFD. 1(1994). 
work on health care quality62 and then dividing "health care system quality controls" into input-based controls such as traditional licensure and accreditation standards, process ${ }^{-}$ based controls such as peer review and professional discipline, and output-based controls. ${ }^{63} \mathrm{He}$ then suggested that most input-based controls involve "at best, conjectures about what kinds of inputs into a black box will yield good results," and that "[w] $\mathrm{w}$. a more direct means of assessing health care outcomes is developed, the utility of their continued use is called into question."64 $\mathrm{He}$ proposed "measuring actual health care outcomes against scientifically derived standards of outcomes," and using the results as a basis for pursuing actions against providers. ${ }^{65}$ Carlson's work, published when quality outcome measures were in their infancy, raised important questions about the future of health care regulation in a world in which such information became widely available.

More than fifteen years after the publication of Carlson's article - in other words, just over twenty-five years ago provider-specific outcome measures did become more widely available. In 1986, the federal government released mortality statistics for individual hospitals nationwide, garnering media coverage across the country. ${ }^{66}$ The same year, the Pennsylvania legislature passed legislation mandating quality reporting within the state. ${ }^{67} \mathrm{~A}$ few years later, the independent agency created by Pennsylvania's legislation began to release hospital-specific report cards; in 1992, it began to report on the outcomes of individual heart surgeons. 68 Thus, beginning in the mid-1980s, reporting gave the public a small window into health outcomes at the same time quality issues were commanding the attention of researchers, administrators, and providers.

62 See Carlson, supra note 21, at 859 n.34.

63 Id. at 862 , Figure 1.

64 Id. at 859-60.

$65 I d$ at 861.

66 See Madison, supra note 59, at 72 (describing the release of hospital mortality statistics). For a discussion of the history of quality reporting, see $i d$. at 69-74, 76-80.

67 Id. at $72-73$.

68 Id. at $73-74$. 
As the quality movement became firmly entrenched in the late 1980s and 1990s, health law scholars turned their attention to its implications for the law. In 1989, Barry Furrow effectively captured the rapidly evolving health care quality world with an article entitled "The Changing Role of the Law in Promoting Quality in Health Care: From Sanctioning Outlaws to Managing Outcomes."69 Drawing on Donabedian's work, the article contrasts the traditional focus on "bad medicine" provided by "bad doctors," the sort combated with malpractice cases and professional discipline, with the trend toward institutional quality controls and greater attention to health outcomes. It proposes a variety of government reforms intended to support this evolution, including data mandates that would contribute to the development of accurate outcome data and the tying of financial incentives to health outcomes. ${ }^{70}$ This article was one of the earliest of several articles that analyzed the implications of the increasing availability of health quality data for quality improvement, quality regulation, and public policy more generally. ${ }^{71}$

On the whole, these articles offered optimistic views on the implications of quality measurement for quality regulation and improvement. At the same time, they generally acknowledged the limitations of measurement as a quality tool. In a thoughtful and comprehensive 1988 article on quality regulation, Professor Jost explained that although markets could be a mechanism for assuring quality, they required well-informed consumers to function

69 Barry R. Furrow, The Changing Role of the Law in Promoting Quality in Health Care: From Sanctioning Outlaws to Managing Outcomes, 26 Hous. L. REV. 147 (1989).

70 See id. at 186-88.

71 See, e.g., David A. Hyman \& Charles Silver, You Get What You Pay For: Result-Based Compensation for Health Care, 58 WASH. \& LEE L. Rev. 1427 (2001); John V. Jacobi, Patients at a Loss: Protecting Health Care Consumers Through Data Driven Quality Assurance, $45 \mathrm{U}$. KAN. L. REV. 705 (1997); Maxwell J. Mehlman, Assuring the Quality of Medical Care: The Impact of Outcome Measurements and Practice Standards, 18 L. MED. \& HEALTH CARE 368 (1990); William M. Sage, Regulating Through Information: Disclosure Laws and American Health Care, 99 CoLum. L. REv. 1701 (1999). 
effectively, and consumers faced considerable difficulty in becoming well-informed about quality. ${ }^{72}$ He suggested that while consumer groups offered comparative quality information for some products, such information would be unlikely to become widespread in the health care market, due in part to the information's high costs and public good nature. ${ }^{73}$ While insurers and employers had begun to take an interest in quality, their primary interest was cost, not quality, and they faced challenges in creating and distributing quality information. ${ }^{74}$ In a later article, Professor Jost acknowledged that report cards might help solve the information problem, but then described the many difficulties of creating timely, accurate, relevant report cards that consumers would choose to use..$^{75} \mathrm{He}$ pointed out that managers also face difficulties in effectively using data. ${ }^{76}$

Professor Jost identified a few ways to respond to these problems. To facilitate the creation of quality measures, for example, Medicare's Peer Review Organization data "could also be made available to other payers or directly to consumers to assist in health care decisionmaking." 77 Governments could facilitate the creation and dissemination of comparative quality information. ${ }^{78}$ As data become easier to collect and analyze, licensure boards could seek out "professionals that seem persistently to have bad outcomes." 79 In other words, the task of government should be to refine traditional quality control mechanisms such as licensure to take advantage of newly available quality data, while also building a stronger foundation for quality assurance through markets and management.

All of this work preceded the publication of Crossing the Quality Chasm. In the decade after the report's publication,

72 Timothy Stoltzfus Jost, The Necessary and Proper Role of Regulation to Assure the Quality of Health Care, 25 Hous. L. REV. 525, 558-63 (1988).

$73 \quad I d$. at 564.

$74 \quad I d$ at $566-67$.

75 Jost, supra note 1, at 851-55.

$76 \quad I d$. at 855-57.

77 Jost, supra note 72 , at 595.

78 Jost, supra note 1 , at 858.

79 Jost, supra note 1 , at 864-66. 
considerable effort was devoted to developing quality measures and putting them into regular use. Five years after Crossing the Quality Chasm, the Institute of Medicine published a report on performance measures entitled Performance Measurement: Accelerating Improvement. 80 The National Quality Forum (NQF), which was conceived by a presidential quality commission in 1998 and became operational in 2000, brought together government policymakers, health plans, employers, research organizations, and others to develop consensus standards for performance measures. ${ }^{81}$ Health care quality report cards produced by federal and state government agencies, stakeholder groups, health plans, and private entities became ubiquitous on the Internet. ${ }^{82}$ Government and private initiatives to tie pay for physicians and hospitals to quality measures proliferated during the 2000s. 83

In short, the health care quality world has changed radically over the last twenty-five years. While the law and policy of much of the twentieth century seemed focused on eliminating quackery and remedying harm, quality improvement has now been widely embraced as a goal. Quality measurement efforts over the last twenty-five years have not only helped to establish the need for quality improvement, but have also supplied important tools for achieving this end.

Legal scholars writing toward the beginning of this period recognized the importance of quality measurement, although they might not have fully anticipated the

80 Inst. OF Med., Performance Measurement: ACCElerating IMPROVEMENT (2005).

81 Presentation, Kenneth W. Kizer, The National Quality Forum and Healthcare Consumerism, FEDERAL TRADE COMMISSION (June 11, 2003), http:/wwwftc.gov/ogc/healthcarehearings/docs/030611kizerkennethpdf, Kristin Madison, The Law and Policy of Health Care Quality Reporting, 31 CAMPBELL L. REV. 215, 245 n.141 (2009).

82 See Madison, supra note 81, at 217-20 (providing examples of quality reporting websites); Madison, supra note 59, at 78-80 (detailing federal expansion of quality reporting).

83 See Meredith B. Rosenthal \& R. Adams Dudley, Pay-forPerformance: Will the Latest Payment Trend Improve Care?, 297 JAMA 740,740 (2007) (describing pay-for-performance trend). 
magnitude of the resulting changes. Consumer Reports, for example, overcame any hurdles posed by quality information's costs and public good characteristics, and is now publishing reports on heart surgeon and hospital quality ${ }^{84}$ But there are many questions that remain about the effectiveness, unintended effects, and broader implications of the use of quality measures, including some concerns raised by Jost and other scholars.

As will be discussed in more detail in Part III, policymakers have taken some steps consistent with scholars' recommendations. For example, they have facilitated the development and dissemination of quality measures, and they have begun to tie pay to performance. Other recommendations, such as the recommendation to incorporate quality measures into formal regulatory oversight mechanisms, have not yet been widely adopted. The question, then, is what this all means for the next quarter century of health care quality law and policy.

\section{The NeXt Quarter Century of Health Care Quality LAW AND POLICY: HOPES AND PREDICTIONS}

\section{A. Predictions about Quality Law and Policy}

I begin with a conservative prediction: the shift of focus from addressing incompetence to quality improvement is a permanent shift, or at least one that will persist over the next twenty-five years. As described in Part II, this shift was a function of the growth of evidence-based medicine, an improvement in quality measurement capabilities, and an acknowledgment of continuing deficiencies in health care quality. I see no reason for any of these three things to disappear anytime soon. I therefore predict that the health care system's commitment to quality improvement, with a heavy reliance on systematic quality measurement, will remain.

One reason why this should be an uncontroversial prediction is the sheer volume of initiatives underway that

84 See Doctors \& Hospitals, CONSUMER REPORTS, http:/www. consumerreports.org/cro/health/doctors-and-hospitalsfindex.htm (last visited Apr. 6, 2013). 
either support or make use of quality measures. As numerous commentators have noted, quality measurement is a costly endeavor that could be greatly facilitated through the adoption of electronic medical records.85 In 2009, Congress passed the Health information Technology for Economic and Clinical Health (HITECH) Act, which created a program under which providers adopting electronic health records are eligible for billions of dollars in Medicare and Medicaid incentive payments. ${ }^{86}$ To qualify for these payments, providers must do more than just purchase electronic systems; they must become meaningful users of them. In 2011 and 2012, for example, systems must perform drug allergy checks and incorporate one clinical decision support rule; in 2012, users must submit electronically the relevant data for clinical quality measures. ${ }^{87}$ Proposed meaningful use rules for future years require more intensive use of records in ways that will set the stage for quality improvement. ${ }^{88}$ More than 100,000 providers have now registered for incentives, and adoption of electronic health records appears to be increasing rapidly, setting the stage for more intensive use of quality measures in the future. ${ }^{89}$

85 See, e.g., Jost, supra note 1, at 864 (describing benefits of electronic records for quality measurement); Madison, supra note 53, at 1597 (same); Madison, supra note 53, at 1643 (calling for financial incentives to speed electronic medical record adoption for the purpose of facilitating quality measurement).

86 Nicolas P. Terry, Certification and Meaningful Use: Reframing Adoption of Electronic Health Records as a Quality Imperative, 8 IND. HEALTH L. REV. 43, 49-50 (2011).

87 David Blumenthal \& Marilyn Tavenner, The "Meaningful Use" Regulation for Electronic Health Records, 363 NEW ENG. J. MED. 501, 502-503 (2010).

88 See, e.g., Electronic Health Record Incentive Program - Stage 2, 77 Fed. Reg. 13,698, 13,736 (proposed March 7, 2012) (to be codified at 42 C.F.R. pts. 412, 413 \& 495) (describing record system features required to earn an incentive payment, such as the ability to generate a list of patients with a specific condition or the ability to send out appropriate reminders to patients).

89 David Blumenthal, Implementation of the Federal Health Information Technology Initiative, 365 NEW ENG. J.MED. 2426, 2427-28(2011). 
Quality measurement and reporting have also expanded in ways that increase their usefulness for providers, payers, patients, and others. The National Quality Forum has now endorsed more than 700 performance measures in areas ranging from patient safety to cardiovascular care to surgical care to preventive care. ${ }^{90}$ Numerous states have mandated public reporting of hospital-specific infection rates in the last few years. ${ }^{91}$ The federal government has also significantly expanded its public reporting initiatives. The Department of Health and Human Services' (HHS) Hospital Compare website, for example, added mortality information in 2007, patient experience measures in 2008, and outpatient and emergency care measures in $2010 .{ }^{92}$ If recent activity is any guide, we will be seeing many more quality measures in use in the near future.

The best place to search for clues about the future of quality regulation, however, is probably the Patient Protection and Affordable Care Act of 2010.93 It reinforces the view that quality measurement and improvement activities will not slow down anytime soon. The Affordable Care Act devotes an entire title to quality issues: Title III, Improving the Quality and Efficiency of Health Care. It requires the adoption of a national strategy to improve

90 National QUality ForUM, NQF MEASURe ENDORSEMENT: 2012 MID-YEAR REVIEW 1-2, (2012), available at http:/www.qualityforum.org/ WorkArealinkitaspx?LinkIdentifier=id\&ItemID=71437 (last visited Apr. 6, 2013).

91 See State Legislation \& Initiatives on Healthcare-Associated Infections, CommitTee to Reduce Infection Deaths (updated Oct. 2011), available ath ttp://hospitalinfection.org/legislation.shtml (last visited Apr. 1, 2013).

92 Press Release, U.S. Dep't of Health \& Human Serv., Medicare Enhances Consumer Information on Hospital Care (June 21, 2007), available at http://www.hhs.gov/news/press/2007pres/06/20070621a.html (last visited Apr. 1, 2013); Press Release, U.S. Dep't of Health \& Human Serv., New Web Site Helps Patients Shop for Hospital Care Based on Quality and Price (Mar. 28, 2008), available at http://www.hhs. gov/news/press/2008pres/03/20080328a.html (last visited Apr. 1, 2013); Press Release, U.S. Dep't of Health \& Human Serv., Important New Data Added to Healthcare.gov to Help Americans Understand the State of Quality at America's Hospitals (July 7, 2010), available at http://www. hhs.gov/news/press/2010pres/07/20100707h.html (last visited Apr. 1, 2013).

93 Patient Protection and Affordable Care Act, Pub. L. No. 111-148, 124 Stat. 119 (2010), amended by the Health Care and Education Reconciliation Act of 2010, Pub. L. No. 111-152, 124 Stat. 1029 (2010). 
health care quality. ${ }^{94}$ It calls for the development of new quality and efficiency measures, including outcome measures. ${ }^{95}$ It imposes a general mandate for federal collection and reporting of quality data, ${ }^{96}$ and establishes specific reporting programs for entities such as long-term care hospitals and hospice programs, ${ }^{97}$ as well as for physicians. ${ }^{98}$ The Affordable Care Act also mandates the sharing of Medicare claims data with private entities for the purpose of facilitating the evaluation of "quality, efficiency, effectiveness, and resource use."99 This step responds to longstanding requests of employers and others to access this data, and partially addresses concerns that fragmented access to data holdings impede the creation and dissemination of reliable quality measures. ${ }^{100}$

94 Patient Protection and Affordable Care Act $\S 3011,42$ U.S.C. $\S$ 280j (2012); REPORT TO CONGRESS: NATIONAL STRATEGY FOR QUALITY IMPROVEMENT IN HEALTH CARE, available at http://www.healthcare.gov/ law/resources/reports/quality03212011a.html (last visited Apr. 1, 2013).

95 Patient Protection and Affordable Care Act $\S \S 3013-3014,42$ U.S.C. $\S 299 b-31$ (2012).

96 Patient Protection and Affordable Care Act $\S 3015,42$ U.S.C. $\S$ 280j-1 (2012).

97 Patient Protection and Affordable Care Act $\S 3004,42$ U.S.C. $\S \S$ 1395ww(m) \& 1395ww(j) (2012).

98 Patient Protection and Affordable Care Act $\S 10331,42$ U.S.C. $\S$ 1395w5 (2012).

99 Patient Protection and Affordable Care Act $\S 10332,42$ U.S.C. $\S$ 1395kk (2012); Availability of Medicare Data for Performance Measurement, 76 Fed. Reg. 76,567 (Dec. 7, 2011) (codified at 42 C.F.R. pt. 401).

100 See Madison, supra note 53, at 1642-43 (referring to employers' desire for data and arguing that federal data should be shared); Mark Schoofs \& Maurice Tamman, In Medicare's Data Trove, Clues to Curing Cost Crisis, WALL ST. J., Oct. 25, 2010, http://online.wsj.com/article/ SB10001424052748704696304575538112856615900.html (last visited Apr. 6, 2013) (describing a 1970s-era injunction limiting sharing of Medicare claims data and recent efforts to fight it); Press Release, Consumers' Checkbook, Consumer Organization Praises Government's Plans to Release Medicare Data to Help Consumers, Improve Health Care System (Dec. 6, 2011), available at http://www.checkbook. org/press/doc/CHECKBOOK_Medicare_Claims_\%20Data_Press_Release _12-6-11.pdf (describing new regulations governing Medicare data sharing and critiquing their limitations). 
The Affordable Care Act also builds on the federal government's previous experiments in using financial incentives to promote health care quality. ${ }^{101}$ It supplies parameters for a value-based purchasing program that ties hospital payment to quality measures, ${ }^{102}$ reduces payments to hospitals in which patients suffer from unusually high levels of hospital-acquired conditions, ${ }^{103}$ and provides for physician payment adjustments "based upon the quality of care furnished compared to cost." 104 It establishes a shared savings program that allows providers to financially benefit from Medicare savings they obtain, but only if they attain a minimum level of performance on health care quality measures. ${ }^{105}$ It also requires that qualified health plans offered through the Affordable Care Act's state health benefit exchanges make use of payment structures that reward quality. ${ }_{106}$

Through all of these initiatives, the Affordable Care Act continues the previous trajectory of federal involvement in quality improvement efforts. It strengthens the infrastructure for health care quality measurement and expands on previous programs to incentivize quality improvement. It embodies a long-term federal commitment to the systematic use of quality measures in an effort to improve quality. Despite the political uncertainty over the long-term future of the Affordable Care Act, there does not

101 See generally Lyle Nelson, Lessons from Medicare's Demonstration Projects on Value-Based Payment, (Congressional Budget Office, Working Paper No. 2012-02, 2012), available at http://www.cbo.gov/sites/defaultfiles/cbofiles/attachmentsWP2012-02_Nelson_Medicare_ VBP_Demonstrations.pdf (describing Medicare's value-based purchasing demonstration projects and analyzing their reported results).

102 Patient Protection and Affordable Care Act $\S 3001,42$ U.S.C. $\S$ 1395ww (2012).

103 Patient Protection and Affordable Care Act $\S 3008,42$ U.S.C. $\S$ 1395ww (2012).

104 Patient Protection and Affordable Care Act $\S 3007,42$ U.S.C. $\S$ 1395w-4 (2012).

105 Patient Protection and Affordable Care Act $\S 3022,42$ U.S.C. 1395jjj(b)(3) (2012).

106 Patient Protection and Affordable Care Act $\S \S 1311(\mathrm{c})(1)(\mathrm{E})$, 1311(g)(1), 42 U.S.C. § 18031 (2012). 
seem to be any concerted effort to abandon this commitment.

As the federal involvement in quality measurement and reporting efforts grows, the direction of state and thirdparty involvement in similar quality initiatives is uncertain. Federal programs have the potential to crowd out other programs, particularly in the reporting area. In 2011, the California Hospital Association announced its decision to withdraw its support for a multistakeholder organization that had been publishing California hospital report cards for several years, citing, among other factors, the public availability of data through the federal Hospital Compare website. ${ }^{107}$ In Ohio, the Ohio Hospital Association has supported a bill that would end state reporting, again citing the fact that quality data is available at Hospital Compare. ${ }^{108}$ The author of a recent study on state infection reporting suggests that "states slowed down their [public reporting] efforts because people assumed that this is a cause that's going to be taken on by Medicare."109

At the same time, however, there is reason to expect continued and perhaps even expanding state and thirdparty involvement in quality measurement-based initiatives in the future. This is most obviously the case in measure development, where provider groups will likely want to

107 Stephanie Teleki \& Maribeth Shannon, In California, Quality Reporting at the State Level is at a Crossroads After Hospital Group Pulls Out, 31 HEALTH AFF. 642, 642 (2012) ("In late 2011 the California Hospital Association's board of trustees voted to withdraw the organization's support from the initiative, noting declining value to users, costs of data collection, and the fact that the Center for Medicare and Medicaid Services' Hospital Compare website obviated the need for the state-based reporting effort."); id. at 643 (describing the Hospital Association's comments in more detail).

108 Ben Sutherly, Hospitals Support Repeal of Data Rule, DAYTON DAILY NEWS, Dec. 4, 2011, http://www.daytondailynews.com/news/ news/state-regional/hospitals-support-repeal-of-data-rule-1/nMxcX/ (last visited Apr. 6, 2013).

109 Kevin B. O'Reilly, Only 14 States Post Hospital Data on Surgical Site Infections, AM. MED. NEwS, April 2, 2012, http://www.amaassn.org/amednews/2012/04/02/prsb0402.htm (last visited Apr. 6, 2013) (statement of Martin A. Makary). 
continue or expand on their current involvement ${ }^{110}$ in order to shape the measures that will be used for their evaluation or compensation. Payers of all sorts will also want to remain involved in developing quality measures and incentive programs, given the demands placed on them by customers, beneficiaries, and others. State Medicaid programs, for example, have experimented with a variety of pay-forperformance programs, ${ }^{111}$ and private payers are likely to continue to tie pay to quality as well.

State and third-party involvement has the potential to grow in the reporting area, too. Increased federal involvement in quality measurement and reporting may reduce the incremental value of other report cards, but it may also reduce their costs. Federal support may therefore make public reporting a viable proposition for a larger cross-section of organizations, allowing them to turn their attention to the task of aggregating and presenting federally-developed quality measures in ways well-suited to the needs of their targeted users. ${ }^{112}$

More widely available, more tailored, and/or more polished presentations of quality data might help to address the lack of consumer engagement that has hindered reporting's effectiveness as a quality improvement tool. A 2007 California survey found that less than a quarter of

110 See 2012 Physician Quality Reporting System (Physician Quality Reporting) Measures List, CTR. FOR MEDICARE \& MEDICAID SERV., (Dec. 23, 2011) http://www.cms.gov/Medicare/Quality-InitiativesPatient-Assessment-Instruments/PQRS/Downloads/2012_PhysQualRptg _ImplementationGuide_MeasuresList_01162012.zip (last visited Apr. 6, 2013) (listing federal physician quality reporting measures and their developers, including organizations such as the American Academy of Dermatology and the American Heart Association).

111 See, e.g., Judith Graham, Ohio Medicaid Program Raises Stakes for Nursing Homes, KaISER HEALTH NEwS (Aug. 14, 2012), http://www.kaiserhealthnews.org/Stories/2012/August/15/ohio-medicaidnursing-homes.aspx (last visited Apr. 6, 2013) (describing an Ohio Medicaid pay-for-performance program for nursing homes).

112 See Sutherly, supra note 108 (stating that an opponent of the bill that would terminate Ohio's reporting program "said the Ohio website is easier to use than the federal website"); Madison, supra note 81 , at 251 (discussing states' potential roles in publicizing federal quality data). 
individuals had seen physician quality ratings, and that a similar percentage had seen hospital ratings. ${ }^{113}$ Many individuals are not aware of the existence of quality ratings, and ratings can sometimes be difficult to find. The Affordable Care Act's state health benefit exchanges offer an opportunity to address this problem. ${ }^{114}$ They were conceived primarily as a way to facilitate access to insurance coverage, and the Affordable Care Act mandates the dissemination of quality information related to health insurance plans. ${ }^{115}$ The exchanges' websites could, however, evolve into a broader platform for disseminating information to patients and consumers about health, health care, and health care providers, regardless of whether they turn to the exchange for coverage. The more frequently that the public accesses state exchanges through the Internet, the more likely they are to become aware of the quality information that is available. This broader use of exchanges is more a hope than a prediction, given exchanges' early stage of development and their controversial nature. Nevertheless, the point remains that there will be room for nonfederal involvement in expanding public reporting.

One final prediction is that consumer use of quality reporting will grow. Surveys suggest that the use of quality information increased only slightly through the 2000s. ${ }^{116}$ Much of the growth in federal public reporting, however,

113 Cal. HealthCare Found, JUst LoOking: Consumer Use of THE INTERNET TO MANAGE CARE 10 (2008), available at http://www.chcf.org/resources/download.aspx?id=\%7bA4DBB4F4-24A1448C-B7A4-D7F1F27032CA\%7d (last visited Apr. 6, 2013). The survey found that $23 \%$ of respondents saw hospital rating information, $2 \%$ considered a change of provider based on the rating, and $1 \%$ actually made a change; the similar statistics for physicians were $22 \%, 5 \%$, and $2 \%$. $I$ d.

114 Patient Protection and Affordable Care Act $\S 1321,42$ U.S.C. $\S$ 18041 (2012).

115 Patient Protection and Affordable Care Act $\$ 1311(\mathrm{c})(1)(\mathrm{H}), 42$ U.S.C. $\S 18031$ (2012).

116 HeNRY J. KaISER FAMILY Found., 2008 UpDate ON CONSUMERS' VIEWS OF PATIENT SAFETY AND QUALITY INFORMATION 6 (2008), http://www.kff.org/kaiserpolls/upload/7819.pdf (showing that $15 \%$ of survey respondents in 2000 and $20 \%$ of respondents in 2008 had seen quality data on hospitals). 
has occurred in the last five years.117 Moreover, as the population ages, a higher proportion of health care users, and a higher proportion of their caregivers, will have online access and experience searching the Internet for information. A national survey found that as of 2012, only $53 \%$ of adults age 65 or over used the Internet - a significant jump from 2011, when only 41\% did.118 By contrast, over $90 \%$ of adults ages 18 to 49 used the Internet in 2012. ${ }^{119}$ Twenty-five years from now, as these younger adults become more engaged with the health system as caregivers and patients, they are likely to be more proactive than today's older adults in searching for quality information.

Admittedly, reporting will always remain a more important tool for providers, payers, and regulators, than for patients, given the many barriers patients face in using it effectively. ${ }^{120}$ In addition, consumer use may drop if reporting or other quality improvement measures succeed in closing performance gaps. Given the pace of medical progress, however, it seems that there should always be new areas for assessment.

\section{B. Hopes for Quality Law and Policy}

Parts I and II of this essay illustrated how much the health care quality world has evolved over the past century, focusing in particular on the trend toward quality measurebased oversight mechanisms; Part III.A predicted that this trend would continue. This essay has not devoted much attention, however, to the question of whether the trend is a salutary one. In theory, the trend has the potential to greatly enhance quality, but in practice, its impact has been

117 See U.S. Dep't of Health and Human Serv., supra note 92.

118 KATHRYN ZiCKUHR \& MARY MADDEN, PEW RESEARCH CENTER'S INTERNET \& AMERICAN LIFE PROJECT, OLDER ADULTS AND INTERNET USE 4 (2012), available at http://pewinternet.org/Reports/2012/Older-adultsand-internet-use.aspx (last visited Apr. 6, 2013).

119 Id. at 6.

120 Madison, supra note 81 , at $226-33$ (describing barriers to report cards' use and usefulness). 
less clear. ${ }^{121}$ Quality measures may be ignored or inaccurate or misused. If incorporated into reporting or incentive programs, they may encourage providers to avoid sick patients, exacerbate disparities in provider quality and patient health, or divert provider and regulator attention from steps more likely to achieve quality goals. ${ }^{122}$ Or they may simply be absent, leaving a blank or incomplete picture of treatment quality for a particular condition, provider, or patient group. All of these possibilities are worrisome, and the challenges in responding to them are considerable. I will not be able to address these concerns in this essay, but I will say that I remain hopeful that the continuing emphasis on quality measurement and reporting will benefit patients in the long run.

In the remainder of this essay, I describe four more specific hopes for the future of health care quality law and policy.

\section{Improvement in Quality Measurement Capabilities}

For quality measurement to benefit a broader group of patients, quality measurement capabilities will need to improve significantly. Toward this end, it will be important to expand the data available for use in calculating quality measures. The Affordable Care Act provision that allows for the sharing of Medicare data with outside organizations is a significant step, but I hope that even more will be done to

121 Compare Maureen A. Smith et al., Public Reporting Helped Drive Quality Improvement in Outpatient Diabetes Care Among Wisconsin Physician Groups, 31 HEALTH AFF. 570 (2012) with Andrew M. Ryan, Brahmajee K. Nallamothu \& Justin B. Dimick, Medicare's Public Reporting Initiative on Hospital Quality Had Modest or No Impact on Mortality from Three Key Conditions, 31 HEALTH AFF. 585 (2012).

122 See, e.g., Rachel M. Werner, L. Elizabeth Goldman \& R. Adams Dudley, Comparison of Change in Quality of Care Between Safety-Net and Non-Safety-Net Hospitals, 299 JAMA 2180 (2008) (concluding that "[s]afety-net hospitals tended to have smaller gains" and that therefore "[a]n incentive system based on these measures has the potential to increase disparities among hospitals"). For a discussion of previous studies on the impact of quality reporting, see Madison, supra note 81 , at 220-36. 
enlarge the data pool so that we can maximize the accuracy and reliability of measurement. Professor Harold Luft recently proposed a means of accomplishing this goal, and it seems to be a step in the right direction. ${ }^{123}$

I also hope that we will be able to develop, systematically collect, and use better measures of health outcomes. Because of the need to take into account differences in underlying patient characteristics, outcomes can be very difficult to measure properly. On the other hand, outcome measures are critically important to patients, and their use may encourage quality-enhancing innovation more than process measures would. Outcome measures should include more than just mortality, although surely patients care about that, and more than the readmissions and complications data currently found on the federal Hospital Compare website. ${ }^{124}$ They should also include measures that indicate the extent to which treatment has improved patients' quality of life, or slowed its deterioration. The patient survey data on Hospital Compare provides one example of this sort of indicator: a question about whether hospital patients' pain was always controlled.125 Broader surveys could be used to capture additional information about patients' perceptions of their own quality of life. Data could also be collected on more objective measures, such as patients' ability to walk or prepare meals. Some measures along these lines already exist, but they are often not systematically collected and recorded.126 Work to develop outcomes measures is

123 Harold S. Luft, Advancing Public Reporting Through a New 'Aggregator' to Standardize Data Collection on Providers' Cost and Quality, 31 HeALTH AFF. 619 (2012).

124 See Find Hospitals: Hospital Compare, CTR. FOR MEDICARE \& MEDICAID SERV., http://www.hospitalcompare.hhs.gov (last visited Apr. 6, 2013).

125 See id. (reporting "Patient Survey Results" for each hospital in the website database).

126 See Sidney T. Bogardus et al., What Does the Medical Record Reveal About Functional Status?, 16 J. GEN. INTERNAL MED. 728 (2001) (finding that most medical records lacked documentation of patients abilities' to engage in activities of daily living). 
underway, 127 but much remains to be done. I therefore predict that the focus on outcomes will increase in the next twenty-five years, but hope for even more. I hope that wellconstructed patient outcome measures become ubiquitous.

I hope that research on quality measurement's impact on quality will continue to accumulate, and that it will begin to dig deeper. Many recent studies evaluate the impact of entire reporting programs in the aggregate; some find an effect, some do not. ${ }^{128}$ While differences in study methodologies may explain the mixed results, it seems likely that differences in program characteristics would matter too. It would be nice to begin to sort out the factors that determine report cards' effects.

I would like to know more about the effects of incorporating patient experience measures into report cards, for example. ${ }^{129}$ The principle of patient-centeredness has captured the attention of the health policy community, ${ }^{130}$ and patient experience measures, such as patient assessment of whether a provider has communicated well, allow for its evaluation. There are many good reasons to support the use of experience measures. They represent dimensions of quality that are important to patients but too often overlooked. Patients may understand them better than technical quality measures, and may be more likely to seek them out. On the other hand, such measures might divert patient, provider, and regulator attention from technical clinical quality measures that have a tighter link with health outcomes. But do they? Does the inclusion of patient experience

127 See, e.g., NQF: Patient Outcomes Measures, NATIONAL QUALITY FORUM, http://www.qualityforum.org/projectsPatient_Outoome_Measures.aspx (last visited Apr. 6, 2013).

128 See Madison, supra note 81.

129 For more discussion of issues raised by patient experience reporting, see Madison, supra note 81, at 229-33.

130 See generally REPORT TO CONGRESS, supra note 94 (identifying "making health care more patient-centered" as a national aim); Hospital Compare, MEDICARE.GOV, http://www.medicare.gov/hospitalcompare/ (last visited Apr. 6, 2013) (placing "Patient Survey Results" in a prominent position adjacent to "General Information" in hospital search results). 
measures in measurement, reporting, or incentive programs improve technical quality, or undermine it? ${ }^{131}$ Does it increase the costs of care, as it might if providers try to satisfy patient demands by offering more services? ${ }^{132}$ These are just a few of many questions that remain unanswered about the intended and unintended effects of recentlydeveloped quality tools. I hope that the body of research on these tools will grow significantly over the next twenty-five years, ${ }^{133}$ creating the evidence base necessary to design effective oversight mechanisms.

\section{Consolidation-related Improvements in Quality}

Another of my hopes is that the health care industry's trend toward consolidation will foster further growth in quality. From the 1990s through the mid-2000s, physicians

131 Evidence on the link between various kinds of patient experience measures and technical quality measures is mixed. See, e.g., John T. Chang, Patients' Global Ratings of Their Health Care Are Not Associated with the Technical Quality of Their Care, 144 ANNALS INTERNAL MED. 665 (2006) (finding no relationship between technical quality measures and patients' assessments); Thomas Isaac et al., The Relationship Between Patients' Perception of Care and Measures of Hospital Quality and Safety, 45 HeALTH SERVICES Res. 1024 (2012) (finding a positive relationship between patient experience and technical quality measures); Ashish K. Jha et al., Patients'Perception of Hospital Care in the United States, 359 NEw ENG. J. MED. 1921 (2008) (showing a correlation between clinical quality measures and results on the Hospital Consumer Assessment of Healthcare Providers and Systems survey); Joel M. Kupfer \& Edward U. Bond, Patient Satisfaction and Patient-Centered Care: Necessary But Not Equal, 308 JAMA 139 (2012) (concluding that the medical literature has not established a clear link between satisfaction surveys and the improvement of health outcomes).

132 See Joshua J. Fenton et al., The Cost of Satisfaction, 172 ARCHIVES INTERNAL MED. 405 (2012) (finding that "higher patient satisfaction was associated with less emergency department use but with greater inpatient use, higher overall health care and prescription drug expenditures, and increased mortality"). This result would be particularly problematic if the increased costs exceeded the monetized value of patients' increase in satisfaction.

133 Of course, there is also a need, perhaps even a greater need, for more research on more traditional quality tools, such as medical licensure and malpractice liability. 
began to leave their traditional solo and two-person practices in favor of mid-sized practices and institutions like medical schools. ${ }^{134}$ More recently, hospital employment of physicians has been increasing rapidly, 135 a trend that may accelerate in response to the reforms embodied in the Affordable Care Act. ${ }^{136}$ To be eligible for the financial incentives available under the Affordable Care Act's shared savings program, for example, providers must come together as "accountable care organizations" (ACOs) to take joint responsibility for the care of a group of Medicare beneficiaries. ${ }^{137}$

Formal consolidation through employment relationships and the structures designed to permit coordinated care may signal the beginning of the end of the fragmentation that has made quality improvement so difficult in the past. 138 Greater integration expands the scope for internal quality management and monitoring through peer review mechanisms and management techniques, decreasing the importance of external oversight mechanisms such as professional disciplinary bodies. Greater integration may also facilitate quality measurement. The limited number of patients that each physician sees creates a technical challenge for those seeking to compile accurate quality

134 Allison Liebhaber \& Joy M. Grossman, Physicians Moving to Mid-Sized, Single-Specialty Practices (Tracking Report No. 18, 2007), HEALTH SYSTEMS CHANGE, http://www.hschange.com/CONTENT/941/ (last visited Apr. 6, 2013).

135 Jenny Gold, Hospitals Lure Doctors Away from Private Practice, KAISER HEALTH NEWS (Oct. 13, 2010), http:/www.kaiserhealthnews.org/ stories $2010 /$ october/13hospitals-lure-doctors-away from-private-practioe.aspx (last visited Arp. 6, 2013).

136 J.D. Harrison, Health-Care Law Driving Doctors Away from Small Practices, Toward Hospital Employment, WASH. PosT, July 19, 2012, http://articles.washingtonpost.com/2012-07-19business/35489044_1_primarycarephysicianshealth-care-reform-law acoountable-care-onganizations (last visited Apr. 6, 2013).

137 Patient Protection and Affordable Care Act $\S 3022$, 42 U.S.C. 1395jjj (2012).

138 See generally The Fragmentation of U.S. HEAlTH CARE: CAUSES AND SOLUTIONS (Einer Elhauge ed., 2010) (exploring the implications of fragmentation in the U.S. health care system). 
measures for individual physicians. ${ }^{139}$ If truly integrated organizations put in place effective clinical protocols and robust quality oversight mechanisms, however, then a patient's experience will depend less on the patient's idiosyncratic relationship with a single provider, than on the care system developed by the organization as a whole. Technical quality ratings of the entire organization would then become nearly as meaningful to patients as ratings of a single practitioner - and more reliable, given the broader patient base from which they draw. I hope that this hypothesis proves to be true, so that increased consolidation results in a more robust set of quality management tools, rather than merely impeding the competitive process that might otherwise result in better health care quality.

\section{Stronger External Oversight Mechanisms}

As Parts II and III explained, quality measures are now deployed throughout the health care system. In the last twenty-five years, health care managers have begun to turn to quality measures to monitor care within their own institutions; consumers, to choose providers; and payers, to reward quality. Interestingly, though, quality measures do not seem to have been incorporated into the more traditional mechanisms for responding to poor quality, tort liability and licensure.

In the case of malpractice law, quality measures have proven to be an awkward fit. There may be a connection between quality measures and standards of care, in that clinical guidelines may shape both. Previous authors have explored the relationship between practice guidelines and malpractice standards. ${ }^{140}$ But ultimately, to win a

139 See Timothy P. Hofer et al., The Unreliability of Individual Physician "Report Cards" for Assessing the Costs and Quality of Care of a Chronic Disease, 281 JAMA 2098 (1999).

140 See Michelle Mello, Of Swords and Shields: The Role of Clinical Practice Guidelines in Medical Malpractice Litigation, 149 U. PA. L. REV. 645 (2001); Arnold Rosoff, Evidence-Based Medicine and the Law: The Courts Confront Clinical Practice Guidelines, 26 J. Health PoL. POL'Y \& L. 327 (2001); Arnold J. Rosoff, The Role of Clinical Practice 
malpractice case, a patient must establish that a specific provider's services to the patient fell below the requisite standard. A provider's individual score on a quality measure cannot accomplish this task, because it says little about the care provided to a particular patient. It seems unlikely that a provider's score on a quality measure would have a significant impact on the outcome of malpractice litigation. ${ }^{141}$

There is more room for the use of quality measures, however, in activities undertaken by external oversight organizations. The Joint Commission, which accredits hospitals, has moved in this direction; in 2012, it began requiring hospitals to meet a target performance level on a subset of quality measures. ${ }^{142}$ Medical specialty boards do not condition re-certification on physician performance as reflected in quality measures, but they do require physicians to participate in programs in which the physicians evaluate their own performance. ${ }^{143}$ State medical boards are currently moving toward maintenance-oflicensure requirements patterned after specialty boards'

Guidelines in Healthcare Reform: An Update, 21 AnNALs Health L. 21 (2012).

141 See generally Aaron S. Kesselheim, Timothy G. Ferris \& David M. Studdert, Will Physician-Level Measures of Clinical Performance Be Used in Medical Malpractice Litigation?, 295 JAMA 1831 (2006).

142 Press Release, The Joint Commission, Joint Commission Annual Report Names Top Performing Hospitals (Sept. 14, 2011), available at http//finanoe.yahoo.com/news/Joint-Commission-Annualiw-1990486421.html (last visited Apr. 6, 2013) ("Beginning January 1, 2012, Joint Commission-accredited hospitals will be required to meet a new performance improvement requirement that establishes an 85 percent composite compliance target rate for performance on accountability measures."); see also Madison, supra note 53, at 1605 (briefly describing earlier Joint Commission involvement in quality measurement activities).

143 See Self-Evaluation Overview, AMERICAN BOARD OF INTERNAL MEDICINE, http://www.abim.org/moc/self-eval.aspx (last visited Apr. 11, 2013) (describing evaluation requirements for maintenance of certification); Christine K. Cassel \& Eric S. Holmboe, Credentialing and Public Accountability: A Central Role for Board Certification, 295 JAMA 939, 940 (2006) (discussing relationship between credentialing and quality measures). 
maintenance of certification requirements. ${ }^{144}$ If states adopt the proposed framework, physicians seeking to renew their licenses would be required to use data to evaluate their practices. ${ }^{145}$

What state medical boards have not done is to systematically incorporate physician-specific quality measures in their oversight processes. Today, as in the past, board disciplinary actions are complaint driven. Rather than engaging in regular monitoring of physician practice, boards respond to complaints that bring to their attention potentially problematic physician actions. ${ }^{146}$ I hope that medical boards will someday be able to use poor performance on quality measures to identify providers for whom closer scrutiny may be appropriate, much as the state of Michigan requires an investigation in the wake of multiple malpractice payments. ${ }^{147}$ It is true that many physicians would already be subject to such scrutiny through other forms of peer review (and perhaps public reporting), and that the number of physicians in this category is likely to expand as more physicians join larger institutions. Increased medical board oversight, however, would be helpful in ensuring some level of scrutiny for physicians who fall through the cracks of these systems. ${ }^{148}$ For this hope to become reality, physician-specific quality metrics will have to be more fully developed, and medical boards will require more resources to engage in the reviews that would be triggered.

144 James N. Thompson \& Lisa A. Robin, State Medical Boards: Future Challenges for Regulation and Quality Enhancement of Medical Care, 33 J. LEGAL MED. 93, 107 (2012) (describing performance in practice requirement of maintenance of licensure framework).

$145 I d$.

146 Id. at 104.

147 MICH. COMP. LAWS $§ 333.16231$ (2012).

148 Cf. Jost, supra note 1 , at 865 (suggesting that in using quality data to engage in regulatory functions, "licensure agencies should focus on those practitioners who are relatively free from managerial or market oversight"). 


\section{Systematic Use of Quality Metrics in All Health- Related Policies and Programs}

The final hope I will address in this essay is that quality measures will be used not just in quality improvement initiatives, but in all policies and programs that have the potential to impact quality. Quality measures may be adopted out of a general concern that quality might not be as good as it could be. A measurement program would then confirm the validity of the concerns, motivate remedial activities, and track whether the activities had been successful. Quality measures could be used to test whether a new staff training program was able to increase the quality of care, for example. But measurement can also serve another purpose: it can track whether initiatives with other goals have influenced quality.

All of these functions are at work in the Affordable Care Act's shared savings program. As previously described, it allows health care providers to create ACOs that take responsibility for a defined group of Medicare beneficiaries. ${ }^{149}$ If an ACO is able to reduce beneficiaries' costs of care below a specified level, it is entitled to keep a portion of the savings it achieves, in addition to receiving payment for the services it provides. ${ }^{150}$ One major function of the program, then, is to provide a financial incentive to reduce program costs. But to take advantage of this incentive, ACOs must also meet the quality standards specified by the Center for Medicare and Medicaid Services (CMS). ${ }^{151}$ The current standards incorporate 33 performance measures in areas such as preventive health, patient experience, and patient safety, ${ }^{152}$ and CMS expects to modify the standards over time to encourage continued

149 See Patient Protection and Affordable Care Act $\S 3022,42$ U.S.C. $§ 1395 \mathrm{jjj}$ (2012).

150 See 42 C.F.R. $\S 425.10$ (2012) (contours of program); 42 C.F.R. $\S$ 425.606 (2012) (shared savings formula).

15142 C.F.R. $\S 425.500$ (2012).

152 See RTI InTERnATIONAL \& TElligen, Accountable CARE ORGANIZATION 2012 PROGRAM ANALYSIS (Dec. 12, 2011), http://www.cms.gov/Medicare/Medicare-Fee-for-Service-Payment/shared savingsprogram/Downloads/ACO_QualityMeasures.pdf. 
quality improvement. ${ }^{153}$ Thus, the quality measures serve two roles in the shared savings program - to ensure that ACOs do not reduce health care quality in their effort to save costs, and to promote health care quality improvement.

Ideally, any new regulation or program with the potential to significantly influence health care quality would be accompanied by a plan to measure its impact. Measurement programs already in place may be sufficient for this purpose in some cases; in others, new measures may need to be crafted specifically for this purpose. A state considering expanding a non-physician's scope of practice, for example, might consider first putting in place a quality measurement program that would allow for evaluation of any quality effects of the change. I hope that as quality measurement tools become less costly, more accurate, and more comprehensive, regulators and policymakers will become more willing to experiment with initiatives that might pose a small risk to health care quality, but that have the potential to achieve other important policy goals, such as reducing cost or promoting access.

\section{CONCLUSION}

This essay has described the tremendous expansion in health care quality initiatives over the past century. While the rate of expansion may slow as we work to improve systems for quality measurement, my hope and prediction is that the focus on quality will remain. My fear is that it may not. Even in an era of slowing rates of health care expenditure growth, ${ }^{154}$ concerns about future spending seem to be intensifying. As Medicare reform and the need for cost control come to dominate the public debate, and the Institute of Medicine's quality and safety reports begin to recede from memory, will attention to quality issues begin to wane?

15342 C.F.R. $\$ 425.500$ (2012).

154 Anne B. Martin et al., Growth in US Health Spending Remained Slow in 2010; Health Share of Gross Domestic Product Was Unchanged from 2009, 31 HEALTH AFF. 209 (2012) (documenting changes in health expenditures). 
In the past, efforts to reduce costs have been swiftly followed by renewed commitments to monitoring quality, and perhaps the next twenty-five years will be no different. Hopefully, funding will continue to be directed toward initiatives that will allow us to assess any tradeoffs made between cost control and quality improvement, if indeed there are any. The last twenty-five years of progress in health care quality law, policy, and practice has built a strong foundation for further quality improvement, if we choose to pursue it. 